'Centro de Salud Pública, Instituto de Investigación e Innovación en Salud, Facultad de Ciencias de la Salud, Universidad Central. Santiago, Chile. ${ }^{2}$ Centro de Ciencias Básicas, Instituto de Investigación e Innovación en Salud, Facultad de Ciencias de la Salud, Universidad Central. Santiago, Chile. ${ }^{3}$ CESFAM Alberto Bachelet Martínez, Corporación Municipal de Salud, Conchalí, Santiago, Chile.

4Escuela de Kinesiología, Universidad San Sebastián. Santiago, Chile. aKinesióloga, Magíster en Farmacología, $\mathrm{PhD}^{\odot}$ en Farmacología. 'Psicólogo, Magíster ${ }^{\odot}$ en Salud Pública.

'Kinesiólogo, Máster en Gerontología Social, Magíster en Dirección y Gestión de la Salud.

${ }^{` M e ́ d i c o, ~ M a g i ́ s t e r ~ e n ~ S a l u d ~}$ Pública y Gestión Sanitaria EASP.

The author(s) declare(s) that there is no conflict of interest regarding the publication of this article. This investigation was supported by Instituto de Investigación e Innovación en Salud, Facultad de Ciencias de la Salud, Universidad Central de Chile, Santiago, Chile.

Recibido el 15 de mayo de 2018, aceptado el 12 de septiembre de 2018.

Corresponding author: Andrea Méndez Centre for Public Health, Centre for Basic Science, Institute for Investigation and Innovation in Health, Central University of Chile. Santiago, Chile. Lord Cochrane 417, Santiago, Chile.

Post code: 8330507. maria.mendez@ucentral.cl

\section{Low rates of participation and completion of pulmonary rehabilitation in patients with chronic obstructive pulmonary disease in primary health care}

\author{
ANDREA MÉNDEZ $Z^{1,2, a}$, PATRICIO LABRA ${ }^{1,3, \mathrm{~b}}$, \\ RAFAEL PIZARRO $\mathrm{A}^{4, \mathrm{c}}$, NELLY BAEZA ${ }^{1, \mathrm{~d}}$
}

\begin{abstract}
Background: Only 6\% of patients with chronic obstructive pulmonary disease $(C O P D)$ participate in pulmonary rehabilitation programs (PR) and only $50 \%$ of those who participate, complete these programs. Aim: To determine rates of $P R$ program participation and completion among patients with COPD in Chile. Material and Methods: Analysis of a database available at the Ministry of Health, which included data of 277491 patients with COPD (55\% females) and their participation in PR programs, between 2014 and 2016. Results: Forty percent of patients were over 75 years of age. Participation rates in $P R$ programs ranged from 2.4 to $2.9 \%$. Rates of completion ranged from 26 to $36 \%$. Conclusions: There is a low rate of participation in $P R$ programs among patients with COPD. Approximately one third of participants complete these programs.

(Rev Med Chile 2018; 146: 1304-1308)
\end{abstract}

Key words: Chronic Obstructive Pulmonary Disease; Exercise; Primary Health Care; Rehabilitation.

\section{Participación y adherencia a programas de rehabilitación pulmonar en pacientes con EPOC en Chile}

\footnotetext{
Antecedentes: solo el 6\% de los pacientes con enfermedad pulmonar obstructiva crónica.(EPOC) participa en programas de rehabilitación pulmonar. (RP) $y$ solo el 50\% de los que participan, completan estos programas. Objetivo: Determinar los indices de participación y adherencia a programas de RP entre los pacientes con EPOC en Chile. Material y Métodos: Análisis de una base de datos disponible en el Ministerio de Salud, que incluía datos de 277,491 pacientes con EPOC (55\% mujeres) y su participación en programas de RP, entre $2014 y$ 2016. Resultados: el cuarenta por ciento de los pacientes tenían más de 75 años de edad. Tasas de participación en programas de RP osciló entre 2,4 y 2,9\%. Las tasas de finalización oscilaron entre el 26 y el 36\%. Conclusiones: Existe una baja tasa de participación en programas de RP entre pacientes con EPOC. Aproximadamente un tercio de los participantes completan estos programas.

Palabras clave: Atención Primaria de Salud; Ejercicio; Enfermedad Pulmonar Obstructiva Crónica; Rehabilitación.
} 
Thronic Obstructive Pulmonary Disease (COPD) is a chronic pulmonary condition that affects the quality of life. It is characterized by airflow obstruction, inflammation and emphysema ${ }^{1}$. COPD is the third cause of death in the world ${ }^{2}$. Its prevalence is $4-10 \%{ }^{3}$ and $14.5 \%$ in Chile ${ }^{4}$.

COPD is considered a systemic inflammatory disease, with a poor correlation between airflow limitation, symptoms and prognosis ${ }^{5,6}$. Thus, incorporation of resources as PR, that improves tolerance of exercise, function of peripheral muscles, quality of life, and reduces hospitalizations, is needed ${ }^{6-8}$. Therefore, the Ministry of Health in 2013 adapted a protocol of PR for Primary Health Care which consists on behavioral education and physical training 2 or 3 times a week for 3 months?.

Although PR is effective, studies have shown that it is not widely used. In Canada, $1.2 \%$ of patients with COPD had access to $\mathrm{PR}^{10}$. In Spain, $1-2 \%$ of hospitalizations by COPD had access to $\mathrm{PR}^{11}$. In the UK, $64 \%$ of patients with COPD fulfilled criteria to attend at $\mathrm{PR}^{12}$, similar to Denmark, where $67 \%$ fulfilled criteria ${ }^{13}$, however, solely $6 \%$ of patients were referred ${ }^{12}$. In France, $86 \%$ of patients with COPD had never participated in $\mathrm{PR}^{14}$. In addition, completion of $\mathrm{PR}$ in the $\mathrm{UK}$ reaches $40-60 \%$ of patients that begin $\mathrm{PR}^{8,12}$. In Canada, $80 \%$ of referred patients completed $\mathrm{PR}^{10}$. However, participation and completion of PR in Chile have not been determined.

Therefore, we aimed to determine participation and completion of patients with COPD in PR, in Chile, 2014-2016.

\section{Methods}

\section{Study}

A descriptive, observational, retrospective study was designed.

\section{Population}

National database of patients with COPD in treatment in Primary Health Care, obtained from Health Statistics and Information Department (DEIS), was used. Registers of patients with COPD between 2014-2016, and patients that attended and completed PR were included. Diseases different of COPD and activities in other programs of rehabilitation were excluded.

\section{Measures}

Variables were collected from an on line database, which included: patients with COPD in treatment, participation in PR, attendance assessment, age, gender, year of register and localization of patients. Attendance assessment was obtained in categories "completion" and "drop-out", being drop-out an attendance inferior to 17 sessions. Age in years was obtained in categories 40-54, 55-64, 65-74, and 75+. Localization of patients was determined in two dimensions: "region" and "Service of Health".

\section{Statistic analysis}

Measurement of the variables participation in $\mathrm{PR}$, and attendance assessment was performed by absolute and relative frequency, depending on age, gender, year of register and localization.

Shapiro-Wilk Test was used to determine distribution of data at national level. For parametric

Table 1. Demographic characterization of patients with COPD in treatment, Chile, 2014-2016

\begin{tabular}{|c|c|c|c|}
\hline Variable & $\begin{array}{c}2014 \\
n \quad(\%)\end{array}$ & $\begin{array}{c}\text { Year } \\
2015 \\
\text { n (\%) }\end{array}$ & $\begin{array}{c}2016 \\
\text { n } \quad(\%)\end{array}$ \\
\hline \multicolumn{4}{|l|}{ Age (years) } \\
\hline $40-54$ & $7,297 \quad(9.0)$ & $7,951 \quad(8.5)$ & $8,171 \quad(7.9)$ \\
\hline $55-64$ & $16,058(19.8)$ & $18,411(19.7)$ & 20,493 (19.9) \\
\hline $65-74$ & $26,192(32.3)$ & $30,224(32.3)$ & $32,707(31.8)$ \\
\hline $75+$ & 31,563 (38.9) & 36,876 (39.5) & $41,547(40.4)$ \\
\hline \multicolumn{4}{|l|}{ Gender } \\
\hline Female & $44,363(54.7)$ & $51,393(55.0)$ & $56,474(54.9)$ \\
\hline Male & $36,747(45.3)$ & $42,070(45.0)$ & $46,444(45.1)$ \\
\hline
\end{tabular}


A

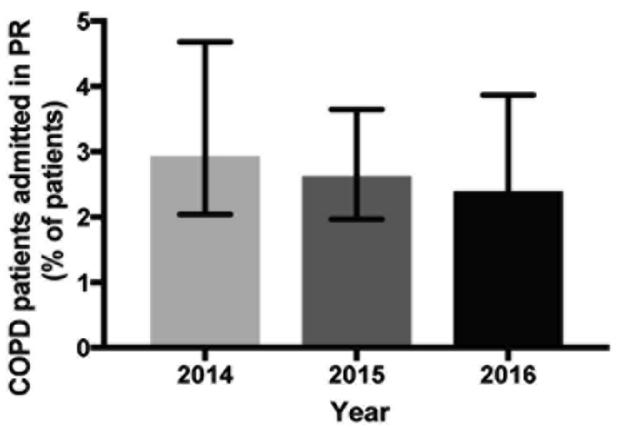

B
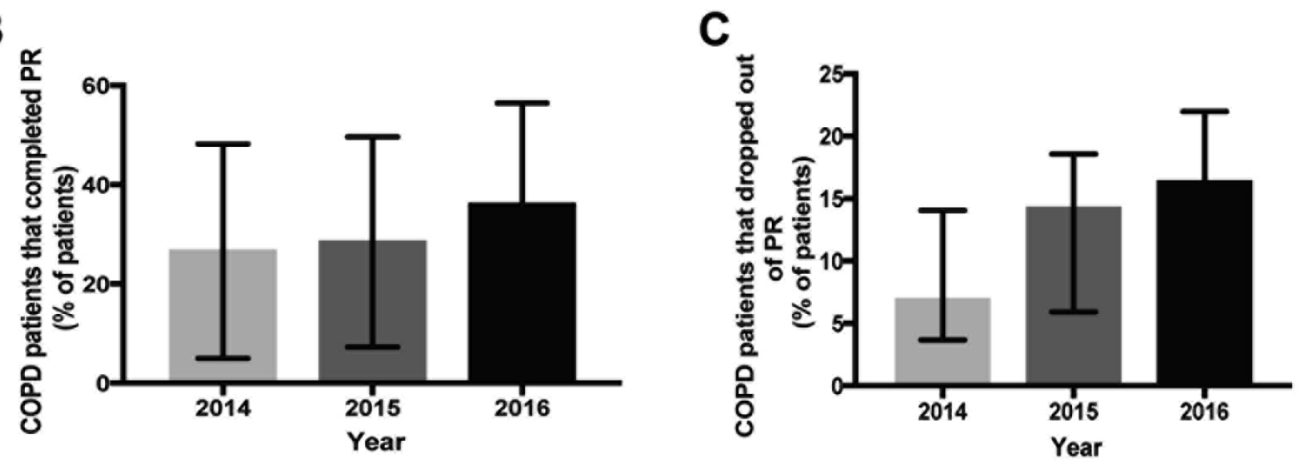

Figure 1: Participation, completion and drop-out of PR at national level. A. Percentage of patients with COPD that participated in PR at national level depending on year of register. Data is presented as median and interquartile range. B. Percentage of patients with COPD who completed PR at national level depending on year of register. Data is presented as mean \pm SD. C. Percentage of patients with COPD who dropped out of PR at national level depending on year of register. Data is presented as median and interquartile range. All of data were calculated from percentage of patients with COPD admitted, who completed and who dropped out of PR in every region, therefore $n=15$.

data, mean \pm standard desviation were used. For nonparametric data, median and interquartile range were used.

Outliers were deleted by software, specifically percentages of participation in PR over $15 \%$, considering the maximum participation reported $(14 \%)^{14}$.

Analyses were performed by SPSS 24 Software (IBM Corporation, Armonk, NY, USA) and Prism GraphPad 7.0 Software (GraphPad Software Inc, San Diego, CA, USA).

\section{Results}

Patients with COPD in treatment between 20142016 were mainly $75+$ years, female.

To characterize the population of patients with COPD, frequency of patients depending on age and gender was determined. A higher frequency in 75+ in 2014-2016 was observed (38.9, 39.5 and $40.4 \%$, respectively), and a higher frequency of female patients in 2014-2016 was observed (54.7, 55.0 and $54.9 \%$, respectively) [Table 1].

\section{Percentage of patients with COPD that participated in PR between 2014-2016} was $2.9-2.4 \%$ at national level.

Considering the total of patients admitted in PR related to total of patients with COPD in treatment, at national level, we observed that $2.9 \%$ of patients with COPD participated in $\mathrm{PR}(\mathrm{IR}=2.0$ $4.7 \%)$ in $2014,2.6 \%(\mathrm{IR}=2.0-3.6 \%)$ in 2015 , and $2.4 \%(\mathrm{IR}=1.5-3.9 \%)$ in 2016 [Figure $1 \mathrm{~A}$ ].

The highest percentages of patients that participated in PR were observed in the north of Chile, with the highest percentage in Arica and Parinacota region in 2015 (9.5\%) [Figure 2] and Arica Service of Health in 2015 (9.5\%) (data not shown). 


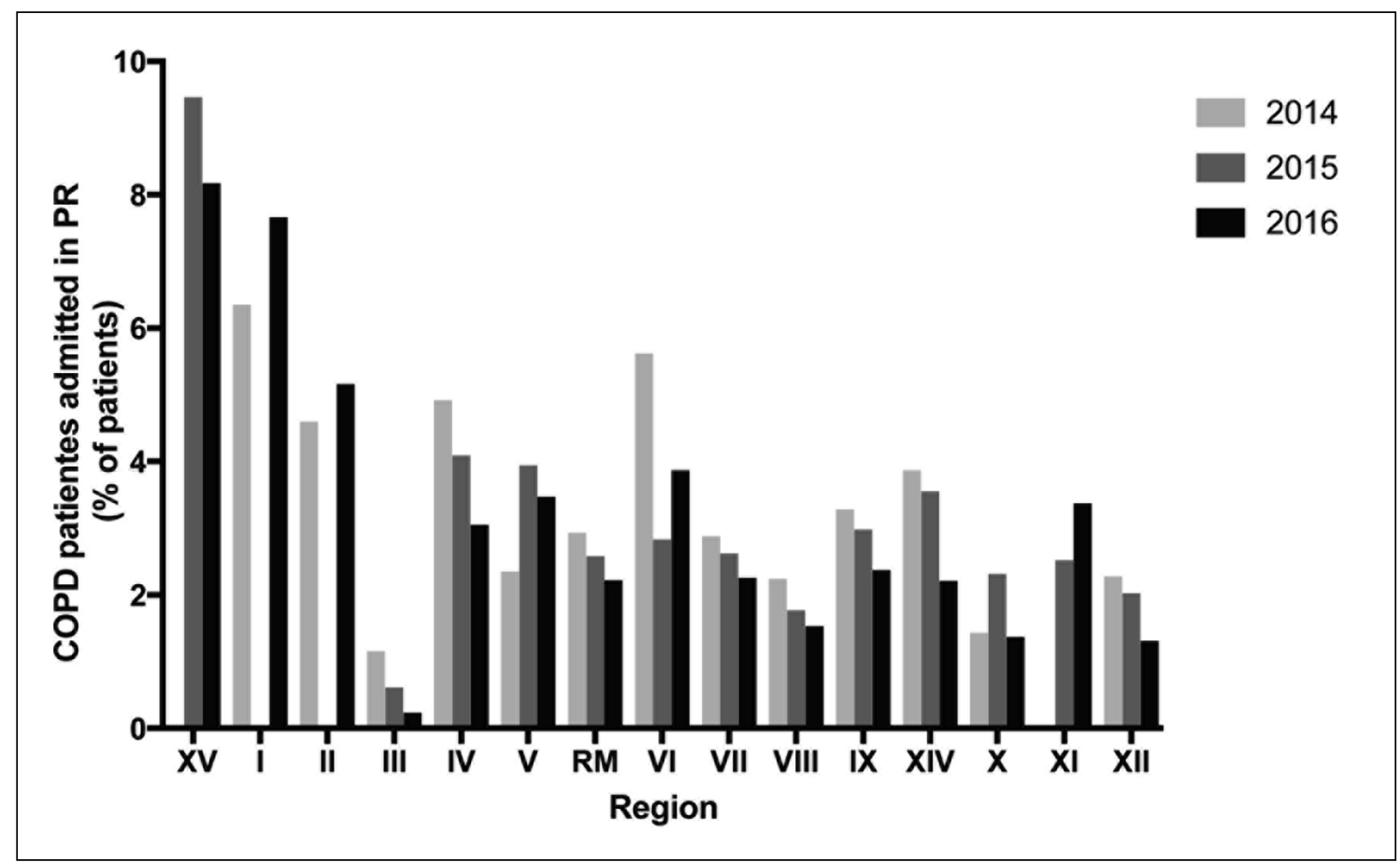

Figure 2. Participation in PR at local level. Percentage of patients with COPD that participated in PR depending on region and year of register. Data represents the relative frequency of patients with COPD admitted to PR in every region.

\section{Percentage of patients that completed PR between 2014-2016 was 26.6-36.1\%}

Considering the percentage of total of patients that completed or dropped out of PR related to total of patients that participated in $\mathrm{PR}$, at national level, we observed that $26.6 \pm 21.6 \%$ of patients completed PR in 2014, 28.5 $\pm 21.2 \%$ in 2015 , and $36.1 \pm 20.4 \%$ in 2016 [Figure $1 \mathrm{~B}$ ]. Considering the frequency of patients who dropped out of $\mathrm{PR}$, we observed $6.9 \%(\mathrm{IR}=3.7-14.1 \%)$ in $2014,14.2 \%$ $(\mathrm{IR}=5.9-18.6 \%)$ in 2015 , and $16.4 \%(\mathrm{IR}=8.5-$ $22.0 \%$ ) in 2016 [Figure 1C].

\section{Discussion}

These findings show that patients with COPD in treatment in Primary Health Care in Chile, between 2014-2016, were mainly 75+ years, female. At national level, the percentage of patients with COPD that participated in PR was 2.9-2.4\%, and the percentage of patients that completed PR was 26.6-36.1\%.

A study characterized these patients, indicating that $55.4 \%$ were female ${ }^{15}$, and a study performed in Chile indicated that $61.1 \%$ were $>60$ years old $^{16}$, which is similar to the current investigation. However, this differs from patients who attend RP, who are 65-74 years and male $e^{8,12}$.

International studies show low rates of referral to PR. In the UK, $6.0 \%$ of patients with COPD was referred $^{12}$. In France, 14\% of patients with COPD had participated in $\mathrm{PR}^{14}$. This results of participation are higher than the present results. Studies accomplished in Canada and Spain that show 1.2\% and $1-2 \%$ of access to PR, respectively ${ }^{10,11}$, were performed 7 and 10 years ago, therefore, they are not current. This finding suggests the necessity of increasing the referral of patients with COPD to PR. Obstacles to refer have not been studied in Chile, therefore, these results support the necessity of studying these factors.

The current investigation showed a decreasing tendency in participation in PR. This could be related to professional training and characteristics of training ${ }^{17}$.

A study from the UK reported that $40-60 \%$ of patients completed $\mathrm{PR}^{8,12}$, which is higher to our results. In Canada, the reasons of drop-out were 
respiratory exacerbations and low rate of satisfaction ${ }^{10}$. In Argentina, a low adherence was reported $(26.3 \%)$ and this was related to socioeconomic variables $^{18}$. In Chile, reasons of drop-out have not been studied. These findings suggest the necessity of knowing those factors.

The present study has some weaknesses related to use of retrospective database and low accuracy of statistical registers, however, this information bias would have been reduced by studying total population and careful register. The availability of information related to characteristics of patients who participated in RP was a limitation of this study.

In conclusion, these findings are the first evidence of participation and completion of $P R$ in COPD at national level. These results are relevant because they allow to evaluate the perfomance, utilisation and adherence to PR, and to focus the efforts towards improving the access.

\section{References}

1. McGuinness AJ, Sapey E. Oxidative Stress in COPD: Sources, Markers, and Potential Mechanisms. J Clin Med 2017; 6 (2). doi: 10.3390/jcm6020021.

2. Lozano R, Naghavi M, Foreman K, Lim S, Shibuya K, Aboyans V, et al. Global and regional mortality from 235 causes of death for 20 age groups in 1990 and 2010: a systematic analysis for the Global Burden of Disease Study 2010. Lancet 2012; 380 (9859): 2095-128. doi: 10.1016/S0140-6736(12)61728-0.

3. Halbert RJ, Isonaka S, George D, Iqbal A. Interpreting COPD prevalence estimates: what is the true burden of disease? Chest 2003; 123 (5): 1684-92.

4. Menezes AM, Perez-Padilla R, Jardim JR, Muiño A, Lopez MV, Valdivia G, et al. Chronic obstructive pulmonary disease in five Latin American cities (the PLATINO study): a prevalence study. Lancet 2005; 366 (9500): 1875-81.

5. Fabbri LM, Rabe KF. From COPD to chronic systemic inflammatory syndrome? Lancet 2007; 370 (9589): 797 9.

6. Di Marco F, Santus P, Sotgiu G, Blasi F, Centanni S. Does Improving Exercise Capacity and Daily Activity Represent the Holistic Perspective of a New COPD Approach? COPD 2015; 12 (5): 575-81.

7. Spruit MA, Singh SJ, Garvey C, ZuWallack R, Nici L, Rochester C, et al. An official American Thoracic Society/European Respiratory Society statement: key concepts and advances in pulmonary rehabilitation. Am J Respir Crit Care Med 2013; 188 (8): e13-64.
8. Hogg L, Garrod R, Thornton H, McDonnell L, Bellas $\mathrm{H}$, White P. Effectiveness, attendance, and completion of an integrated, system-wide pulmonary rehabilitation service for COPD: prospective observational study. COPD 2012; 9 (5): 546-54.

9. Programa de Rehabilitación pulmonar para la Atención Primaria de Salud, Octubre 2013. Unidad de Salud Respiratoria, Ministerio de Salud, Gobierno de Chile [Internet]. Santiago, Chile.

10. Brooks D, Sottana R, Bell B, Hanna M, Laframboise L, Selvanayagarajah $\mathrm{S}$, et al. Characterization of pulmonary rehabilitation programs in Canada in 2005. Can Respir J 2007; 14 (2): 87-92.

11. Miranda G, Gómez A, Pleguezuelos E, Capellas L. Rehabilitación respiratoria en España. Encuesta SORECAR. Rehabilitacion 2011; 45 (3): 247-55.

12. Moore E, Newson R, Joshi M, Palmer T, Rothnie KJ, Singh S. Effects of Pulmonary Rehabilitation on Exacerbation Number and Severity in People With COPD: An Historical Cohort Study Using Electronic Health Records. Chest 2017. doi: 10.1016/j. chest.2017.05.006.

13. Godtfredsen NS, Grann O, Larsen HB, Sørensen TB, Lavesen M, Pors B, et al. Chronic obstructive pulmonary disease (COPD) rehabilitation at primary health-care centres-the KOALA project. Clin Respir J 2012; 6 (3): 186-92. doi: 10.1111/j.1752-699X.2011.00272.x. Epub 2011 Nov 29.

14. Galera O, Grimal G, Bajon D, Darolles Y. Barriers to referral to pulmonary rehabilitation in COPD patients from the perspective of general practitioners. Rev Pneumol Clin 2017; 73 (3): 115-9. doi: 10.1016/j.pneumo.2017.03.002. Epub 2017 Apr 18. [Abstract].

15. Alvear G, Figueroa LP, Peña CA. Perfil clínico de los pacientes ingresados al programa EPOC en un consultorio de atención primaria durante 10 años. Rev Chil Enf Respir 2015; 31: 17-26.

16. Flores C, Solís MT, Fortt A, Valdivia G. Sintomatología respiratoria y enfermedad pulmonar obstructiva crónica y su asociación a contaminación intradomiciliaria en el Área Metropolitana de Santiago: Estudio Platino Association between indoor pollution, respiratory symptoms and COPD in Santiago, Chile: PLATINO Study. Rev Chil Enf Respir 2010; 26 (2): 72-80.

17. Castillo A, Ferrer L, Masalán P. Capacitación del personal de salud, evidencia para lograr el ideal. Horiz Enferm 2015; 26 (1): 29-37.

18. Boim C, Caberlotto O, Storni M, Cortiñaz M, Monti F, Khoury M. Adherencia a un programa interdisciplinario de rehabilitación respiratoria. Medicina (B. Aires) 2014; 74 (2): 104-9. 